\title{
Research observation: Desert bighorn sheep diets in north- western Sonora, Mexico
}

\author{
LUIS A. TARANGO, PAUL R. KRAUSMAN, RAUL VALDEZ, AND ROBERT M. KATTNIG
}

Authors are Wildlife Professor, Department of Wildlife, Campus-SLP Colegio de Postgraduados, Salinas de Hidalgo, San Luis Potosi-Mexico, 78600; Professor of Wildlife and Fisheries Science, School of Renewable Natural Resources, The University of Arizona, Tucson, Ariz 85721; Wildlife Professor, Department of Fishery and Wildlife Sciences, New Mexico State University, Las Cruces, N.M. 88003; Associate Specialist; Department of Animal Sciences, The University of Arizona, Tucson, Ariz. 85721. At the time of the research, the senior author was a Ph.D. Student in Wildlife and Fisheries Sciences, School of Renewable Natural Resources, The University of Arizona, Tucson, Ariz.

\begin{abstract}
We used microhistological analyses of fresh fecal pellets to determine seasonal diets of desert bighorn sheep (Ovis canadensis mexicana Merriam 1901) in northwestern Sonora, Mexico from April 1997 to December 1998. We identified 41 plant species (22 browse, 10 forbs, 5 grasses, and 4 succulents) in diets of bighorn sheep. We found no differences between diets of males and females, and diet diversity between sexes was similar $(P>0.05)$. Diet included: browse $(45.7 \%)$, forbs $(32.0 \%)$, succulents $(\mathbf{1 7 . 8 \%})$, and grasses $(4.5 \%)$. The consumption of succulents was higher during spring, decreased during summer, increased in autumn, and decreased in winter. Consumption of forbs was higher during winter and summer. Globemallow (Sphaeralceae spp.), desert agaves (Agave spp.), range ratany (Krameria parvifolia Benth.), buck-wheatbrush (Eriogonum spp.), foothill palo verde (Cercidium microphyllum [Torrey] Rose \& Johnst.), Engelmann prickly pear (Opuntia engelmanii Salm-Dyck), desert ironwood (Olneya tesota A. Gray), and elephant tree (Bursera microphylla A. Gray) were consumed throughout the study. As biologists identify potential release sites for restoration of bighorn sheep in Mexico, studies of diet composition will provide managers with information for successful translocations.
\end{abstract}

Key Words: Ovis canadensis mexicana, sexual segregation

Diet composition studies for Mexican bighorn sheep (Ovis canadensis mexicana Merriam) have been conducted in New Mexico (Elenowitz 1983) and Arizona (Alderman et al. 1989, Krausman et al. 1989, Etchberger 1993). In Mexico, the only formal study of diet composition was for Weem's $(O$. c. weemsi Goldman) and peninsular bighorn sheep (O.c. cremnobates Elliot) (Sanchez 1976). Attempts to repopulate areas where bighorns have been extirpated in Sonora, and Baja California Sur have recently been conducted by private organizations and the Mexican government (Jimenez et al. 1996, 1997). In the process of identifying potential release sites, studies of diet composition will provide managers with information essential for successful translocations. The objectives of our study were to identify composition of diets of Mexican bighorn sheep in northwestern Sonora, Mexico and compare diet compositions between sexes and among seasons.

Research was funded by Organización Vida Silvestre (OVIS, A.C.) based in Monterrey city, Nuevo León, MEXICO.

Manuscript accepted 4 Mar. 02.

\section{Resumen}

Utilizamos análisis microhitological de pelotillas fecales frescas para determinar dietas estacionales de las ovejas del bighorn (Ovis canadensis mexicana Merriam 1901) del desierto en Sonora del noroeste, Mexico a parti de abril de 1997 a deiciembre de 1998. Identificamos 41 especies de la planta 22 hojee, 10 forbs, 5 hierbas, y 4 succulents) en dietas de las ovejas del bighron. No encontramos ninguna diferencia entre las dietas de varones y las hembras, $y$ la diversidad de la dieta entre los sexos era similar $(P$ $>0.05)$. Dieta incluida:hojee $(45.7 \%)$, forbs $(32.0 \%)$, succulents $(\mathbf{1 7 . 8 \%})$, and hierbas $\mathbf{4 . 5 \%}$ ). La consumición de succulents era más alta durante el resorte, disminuyó durante el verano, creciente de otoño, y disminuido en invierno. La consumición de forbs era más alta durante invierno y verano. Globemallow (Sphaeralceae spp.), agaves del desierto (Agave spp.), range ratany (Krameria parvifolia Benth.), buck-wheatbrush (Eriogonum spp.), verde del palo de la colina (Cercidium microphyllum [Torrey] Rose \& Johnst.), pera espinosa de Engelmann (Opuntia engelamnii Salm-Dyck), ironwood del desierto (Olneya tesota A. Gray), y el árbol del elefante (Bursera microphylla A. Gray) era consumidor durante el estudio. Pues los biólogos identifican los sitos potenciales del desbloquear para la restauración de las ovejas del bighorn in Mexico, los estudios de la composición de la dieta proporcionarán a encargado quieren la información para los desplazamientos acertados.

\section{Materials and Methods}

This study was conducted in Rancho el Plomito located in the southern portion of Sierra el Viejo about $70 \mathrm{~km}$ south of Caborca, northwestern Sonora, Mexico (30 $12^{\prime}$ and $30^{\circ} 20^{\prime} \mathrm{N}, 112^{\circ} 18^{\prime}$ and $112 \mathrm{o} \mathrm{22}$ ' W) (Fig.1). The privately owned ranch includes 3,576 ha of flat and 4,376 ha of mountainous terrain. Rancho el Plomito contains 9 major canyons and is bordered by private ranches (Fig. 1). There are 2 artificial water tanks (capacity 10,000 liters each) on the ranch and 13 smaller water sources strategically distributed within the ranch to provide water for wildlife. There are also natural water catchments that have been improved for water collection. Livestock were excluded from the ranch in 1994. The ranch is used exclusively for the conservation and management of native wildlife. We selected the study area because of the presence of an indigenous population of Mexican bighorn sheep $(\mathrm{N}=300)$, which is the largest bighorn sheep pop- 


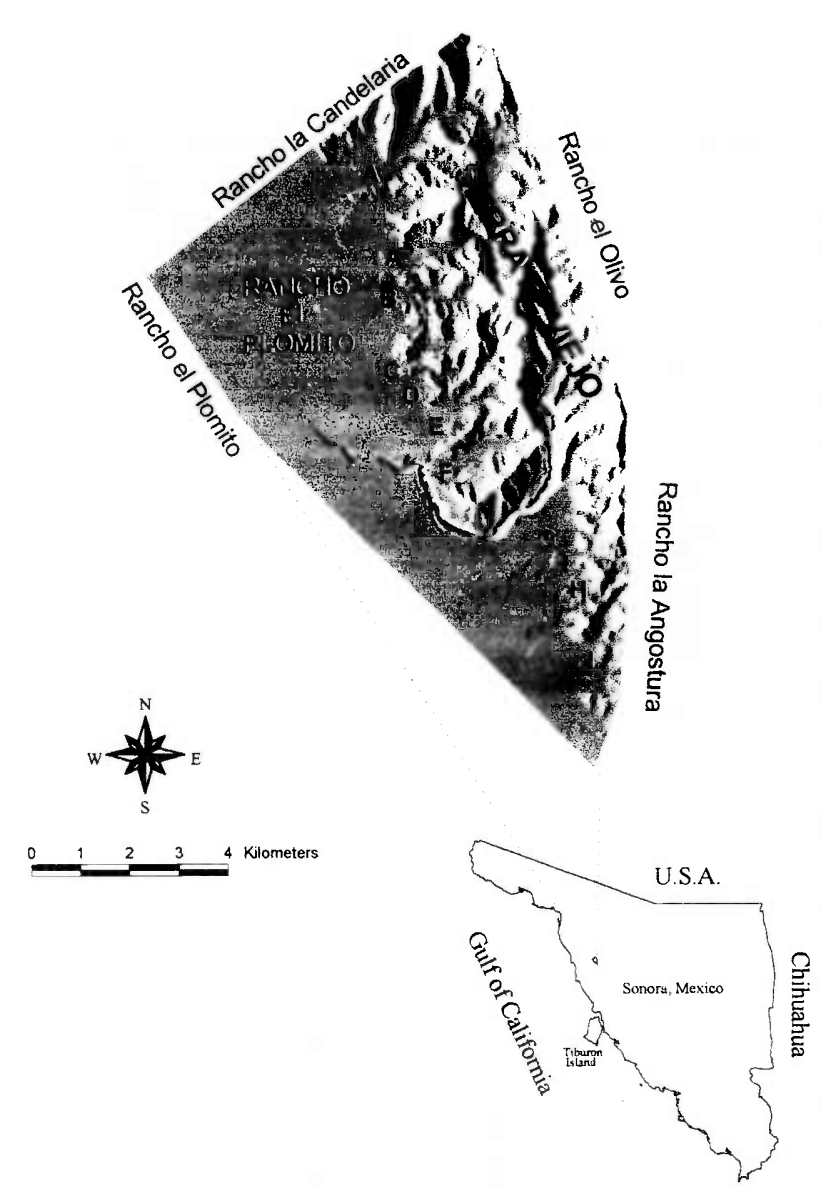

Fig. 1. Rancho el Plomito in Sierra el Viejo, $70 \mathrm{~km}$ south of Caborca, northwestern Sonora, Mexico. The mountain range contained 9 major canyons. A, El Serrucho; B, El Recodo; C, El Coliseo; D, El Solitario; E, San Francisco, F, Puerto la Cueva; G, El Colorado; H, El Muro, and I, Dos Minas.

ulation on the mainland of Sonora (Lee and Lopez-Saavedra 1994).

Rancho el Plomito is located in the Sonoran Desert where the terrain is rugged, rocky, and often interspersed by canyons and washes. The area is Sonoran Desert scrub within the subdivision of the Lower Colorado River Valley, which is the largest and most arid subdivision of the Sonoran Desert (Brown 1994)

Elevations ranged from $300 \mathrm{~m}$ on flat areas to $1,050 \mathrm{~m}$. The mean daily temperature at 0800 for 1997 and 1998 was $26.2^{\circ} \mathrm{C}$ and $22.8^{\circ} \mathrm{C}$, respectively. The lowest mean minimum temperature for both years occurred in autumn (October-December) (i.e., $12.5^{\circ} \mathrm{C}$ in 1997 and $7.8^{\circ} \mathrm{C}$ in 1998), while the highest mean maximum temperature occurred in summer (July- September) (i.e., $41.0^{\circ} \mathrm{C}$ in 1997 and $41.1^{\circ} \mathrm{C}$ in 1998). The annual precipitation for 1997 and 1998 was 227.2 and $148.7 \mathrm{~mm}$, respectively and it rained more during summer in both years (i.e., $169.6 \mathrm{~mm}$ in 1997 and $110.0 \mathrm{~mm}$ in 1998).
Seasons for the study area were determined from the biology of bighorn sheep, bimodal precipitation, and temperature regimes. Seasons were: cold-wet (January -March), hot-dry and peak lambing (AprilJune), hot-wet (JulySeptember), and cold-dry and rut (October- December). However, for convenience, we named the seasons as winter, spring, summer, and autumn, respectively.

We identified 3 vegetation associations within the study area based on field reconnaissance and following Hernandez (1998). The elephant tree (Bursera microphylla A. Gray)-salvia (Salvia mellifera)-limber bush (Jatropha cuneata Wiggins \& Rollins) association (ESL) (2,144 ha) occurs in foothills and mountains on steep slopes. Other dominant plants found within this association are ocotillo (Fouquieria splendens Engelm.), brittle bush (Encelia farinosa A. Gray), opuntias (Opuntia spp.), Mexican jumping bean (Sapium biloculare Wats), desert lavender (Hyptis emoryi Torr.), mammillarias (Mammill-aria spp), hibiscus (Hibiscus denudatus Benth), agaves (Agave spp.), and foothill palo verde (Cercidium microphyllum [Torr.] Rose \& Johnst.). The foothill palo verde-desert ironwood (Olneya tesota A. Gray) association (FDI) (1,138 ha) is commonly found along bajadas and riparian areas (arroyos and washes) and is accompanied with coursetia (Coursetia glandulosa Gray), white-thorn acacia (Accacia greggii A. Gray), brittle bush, garabatillo (Mimosa laxiflora Benth), limber bush, salvia, wolfberry (Lycium californicum Nutt.), range ratany (Krameria parvifolia Benth), and helianthus (Helianthus spp.). The ocotillo-desert agave (Agave zebra Gentry and $A$. pelona Gentry )-hop bush (Dodonoea viscosa Jacq.) vegetation association (OAH) (1,094 ha) occurs at high elevations and is commonly found along ridgetops with scattered foothill palo verde and desert ironwood trees. We followed Lehr (1978) for plant nomenclature.
We determined diets of desert bighorn sheep based on fecal pellets collected 2 times each season from April 1997 to December 1998, except winter, which was only sampled in 1998. We systematically traveled the area on foot across washes, ridgetops and cliffs and observed sheep with a pair of $10 \times 50$ binoculars and a 30 x 16 spotting scope. Sheep were aged and sexed by size and horn development (Geist 1968).

We collected fresh fecal pellets from male and female bighorn sheep within 24 hours of deposition; most pellets were collected within 2 hours following deposition. We avoided disturbing the animals. We collected $10-18$ pellets from $>40$ pellet groups for each sex/season. Fecal samples were air dried and stored in paper bags until analyses at the Fecal Analyses Laboratory of the University of Arizona. Diets were analyzed by microhistological examination of fecal samples (Sparks and Malecheck 1968). Although some disadvantages related to differential digestibility of forage plants has been reported in the use of this technique (Holechek et. al. 1982, Gill et al, 1983), we assumed that the bias equally affected composition of diets of males and females.

We randomly prepared a composite sample from fecal-pellet samples per sex/season (Holechek and Vavra 1981). Ten slides were prepared and 20 fields were read from each slide (200 fields/season). Frequency for each plant species was recorded and converted to relative density following Fracker and Brischle (1944:285, table 1). We determined percent relative composition by dividing the density of each plant species that occurred on the slide by the total plant density on that slide and multiplied by 100 . Plant species found in the diet were classified as browse (perennial shrubs), forbs (annual, herbaceous plants), grasses, or succulents (cacti).

Comparisons of diet between males and females by seasons were made using the Morisita index of overlap (Morisita 1959), as modified by Horn (1966) and Zaret and Rand (1971). Diet overlap indexes were calculated with the following formula (Alcoze and Zimmerman 1973):

$$
\mathrm{C}=\frac{2 \sum_{\mathrm{i}=1}^{\mathrm{S} X i Y i}}{\sum_{\mathrm{i}=1}^{\mathrm{s} X i^{2}+Y i^{2}}},
$$

Where $\mathrm{C}$ is the coefficient value, $\mathrm{s}$ is the total number of plant species and $\mathrm{Xi}$ and $\mathrm{Yi}$ are the proportions of the total diet of 
males (X) and females (Y). The value of this coefficient ranges from 0 when no plant species are shared to 1 when diets are equal. Diet overlap is significant when the coefficient of overlap is $>0.60$. We used this index of overlap because it uses the number of plants that overlap and considers the proportions of those plants in the diet. This index has been previously used in studies of composition of diets of desert bighorn sheep (Krausman et al. 1989, Etchberger 1993). Diversity of diets for males and females by seasons were also identified with the Shannon-Wiener index and tested $(\mathrm{P}<$ 0.05 ) for differences between male and female diversity indices (Zar 1996).

\section{Results}

The coefficient of overlap (Morisita 1959) of diets of male and female bighorn sheep for the winter, spring, summer, and autumn was $0.970,0.926,0.972$, and 0.906 , respectively. All values indicated significant diet overlap (i.e., > 60) for all seasons. Male and female bighorn sheep in Sonora consumed the same plant species and used them in similar proportions (Table 1). Those species that contributed the highest percentages of combined diets in both years were: globemallow, desert agave, range ratany, buck-wheatbrush, foothill palo verde, sagebrush (Artemisia spp.), desert ironwood, elephant tree, and Engelmann prickly pear.

Plant diversity in diets of males and females was very similar among seasons ( $P>0.05)$. During winter, spring, summer, and autumn the diversity indices for males were $0.474,0.512,0.506$, and 0.514 , while for females were $0.433,0.513,0.497$, and 0.545 , respectively. Shannon-Wiener diversity indices (Zar 1996) indicated that diets of desert bighorn sheep were less diverse in winter compared to the other seasons. The mean annual composition of categories of forage in diets of males and females was similar (Fig. 1). We identified 41 plant species consumed by desert bighorn sheep from April 1997 to December 1998 in Rancho el Plomito Sonora, Mexico.

Bighorn sheep consumed $\geq 26$ different plant species each season (Table 1 ). However, seasonal diets concentrated on a few plants in all seasons (e.g., in winter 5 plants constituted $69 \%$ and globemallow (Sphaeralcea spp.) constituted > 37\%; spring, 7 plants constituted $58.8 \%$ of the diet; summer, 5 plants made up $50.3 \%$ of the diet; and autumn 7 plants constituted $60 \%$ of the diet) (Table 1).
Table 1 Percent relative composition of plant species in diets of desert bighorn sheep in Rancho el Plomito, Sonora, Mexico.

$\underline{\underline{1997-1998}}$

\begin{tabular}{ccccc}
\hline \hline Species & $\begin{array}{c}\text { Winter } \\
\text { (Jan.-Mar.) }\end{array}$ & $\begin{array}{c}\text { Spring } \\
\text { (Apr.-Jun.) }\end{array}$ & $\begin{array}{c}\text { Summer } \\
\text { (Jul.-Sep.) }\end{array}$ & $\begin{array}{c}\text { Autumn } \\
\text { (Oct.-Dec.) }\end{array}$ \\
\hline
\end{tabular}

Browse

White-thorn

Catclaw acacia

Ragweed

(Ambrosia ambrosoides Cav.)

Sagebrush

(Artemisia spp.)

Fourwing saltbush

(Atriplex canescens [Pursh] Nutt.)

Broom baccharis

(Baccharis sarothroides A. Gray)

Fairy-duster

(Calliandra eriophylla Benth.)

Desert hackberry

Foothill palo verde

Mormon-tea

(Ephedra spp.)

Buck-wheatbrush

Ocotillo

Snake-weed

(Gutierrezia sarothrae [Pursh] B. \& R.)

$\ldots \ldots \ldots \ldots$ (\%) $\ldots \ldots \ldots$

Haploppapus

(Haploppapus tenuisectus [Greene] Blake)

Range ratany

Wolf berry

Lycium spp.

Desert ironwood

Elephant tree

Brittle bush

Velvet mesquite

(Prosopis velutina Woot.)

Russian thistle

Jojoba

No. species

Forbs

Fringed amaranthus

(Amaranthus fimbriatus [Torr.] Benth.)

Milk-vetch

(Astragalus spp.)

Borage

(Boraginaceae spp.)

Hyssop spurge

(Euphorbia spp.)

Janusia

(Janusia spp.)

Sida

(Sida spp.)

Globemallow

Tidestromia

(Tidestromia lanuginosa [Nutt] Standl.)

Trixis

(Trixis californica Kellogg)

Unidentified

No. species

Grasses

Three-awn

(Aristida spp.)

Grama grass

(Bouteloa spp.)

Red brome

(Bromus spp.)

Bush muhly

(Muhlenbergia spp.)

Drop-seed

Sporobolus spp.

No. species

Succulents

Barrel cactus

Prickly pear cactus

Christmas cactus

Desert agaves

No. species

Total no. species

\begin{tabular}{|c|c|c|c|}
\hline- & - & 0.2 & - \\
\hline- & 4.0 & 3.6 & 1.1 \\
\hline 0.4 & 0.6 & 0.7 & 1.9 \\
\hline- & 6.6 & 5.3 & 5.3 \\
\hline 4.1 & 0.2 & 0.2 & 0.3 \\
\hline 0.1 & 1.7 & 0.6 & 0.8 \\
\hline 0.4 & 0.5 & - & - \\
\hline 3.4 & 0.8 & 1.4 & 1.9 \\
\hline 7.3 & 3.9 & 3.0 & 8.0 \\
\hline 0.8 & 0.6 & - & - \\
\hline 7.9 & 5.6 & 8.1 & 8.8 \\
\hline 1.1 & 2.1 & 1.2 & 1.9 \\
\hline 2.3 & - & - & - \\
\hline- & 0.5 & 0.8 & - \\
\hline 8.2 & 12.6 & 8.1 & 7.4 \\
\hline 0.2 & - & - & - \\
\hline 4.4 & 2.3 & 3.9 & 3.7 \\
\hline 1.2 & 5.4 & 3.7 & 4.8 \\
\hline- & 0.6 & 0.4 & - \\
\hline 0.7 & 1.8 & 2.1 & 0.3 \\
\hline- & 0.1 & 0.4 & - \\
\hline 0.1 & 0.5 & 0.1 & 1.2 \\
\hline 16 & 19 & 18 & 14 \\
\hline 0.3 & 0.1 & 0.1 & 0.2 \\
\hline- & 2.1 & 2.2 & 3.7 \\
\hline- & 3.3 & 4.2 & 4.5 \\
\hline 0.4 & - & 1.5 & 0.1 \\
\hline- & 3.9 & 2.8 & 3.4 \\
\hline- & - & 0.5 & 1.0 \\
\hline 37.1 & 8.2 & 18.7 & 13.9 \\
\hline 1.4 & 0.8 & 0.8 & 1.7 \\
\hline- & 0.5 & 1.5 & 0.4 \\
\hline 2.4 & 2.8 & 4.6 & - \\
\hline$\geq 5$ & $\geq 8$ & $\geq 10$ & $\geq 9$ \\
\hline- & 0.3 & 1.5 & - \\
\hline- & 2.3 & 2.9 & 2.9 \\
\hline- & 0.5 & 0.5 & 1.9 \\
\hline 0.1 & 2.2 & 0.6 & 2.1 \\
\hline 0.1 & 0.4 & 0.2 & - \\
\hline 2 & 5 & 5 & 3 \\
\hline- & 0.5 & 0.2 & 0.8 \\
\hline 4.2 & 6.7 & 3.4 & 6.5 \\
\hline 4.0 & - & - & - \\
\hline 8.5 & 15.7 & 10.1 & 10.1 \\
\hline 3 & 3 & 3 & 3 \\
\hline 26 & 35 & 36 & 29 \\
\hline
\end{tabular}


Desert bighorn sheep consumed desert hackberry (Celtis pallida Torr.), foothill palo verde, buck-wheatbrush (Eriogonum spp.), ocotillo, range ratany, desert ironwood, elephant tree, globemallow, Engelmann prickly pear (Opuntia engelmannii Salm-Dyck.), and desert agave throughout the study (Table 1). However, foothill palo verde, buck-wheatbrush, range ratany, globemallow, and desert agave each occurred in $>5 \%$ of the annual diet and constituted $58.0 \%$ of the average annual diet (Table 1).

There was seasonal variation in the use of plants by desert bighorn sheep. Consumption of succulents was higher in spring, decreased during summer and winter and increased in autumn (Fig. 2). In the Harquahala and Little Harquahala mountains bighorn sheep consumed more barrel cactus (Ferocactus acanthodes [Lemaire] B. \& R.) during summer, autumn, and winter (Warrick and Krausman 1989). Weather conditions in the area during spring and autumn are dry. When weather conditions are very dry, bighorn sheep consume barrel cacti and other species of cacti (Sanchez 1976, Alderman et al. 1989, Krausman et al. 1989). Barrel cacti have higher water content than other forage plants and this is a major source of water for bighorn sheep in some areas during dry conditions (Warrick and Krausman 1989). In addition, Etchberger (1993) found that groups of males, females, and mixed groups of bighorn sheep use micro sites with more barrel cacti that random sites. We commonly observed bighorn sheep consuming agaves, prickly pear, and mammillarias. Sheep eat the central portion of the agave by breaking off the spines with their horns and front legs, by hitting, pulling and chewing the leaves until they reach the central portion. Water content in the central stalk of the plant is likely high. Females with lambs occupied areas with higher densities of mammillarias than females without lambs (Tarango 2000). Greater succulent consumption occurred during lambing when lactating females also require more water and energy (Sadlier 1969).

The decrease of succulent plants in the diet of bighorns from spring to summer (rainy season) could be due to the presence of rain water collected in natural catchments (tinajas) that usually lasts for several days. Potholes provided water to bighorn sheep after rains for up to 7 days in western Arizona (Warrick and Krausman 1989). In our study area, bighorn sheep did not drink from manmade catchments. In 1998, during June,
July and August (the hottest period of the year), we monitored the use of a artificial water-tank (capacity, 10,000 liters) constructed for the use of wildlife and never recorded use by sheep. It is likely that bighorn sheep in Sierra el Viejo used desert agaves, Engelmann prickly pear, desert Christmas cactus (Opuntia leptocaulis DC.), barrel cactus, and mammillarias to fulfill their water requirements. The high consumption of agaves in Sierra el Viejo could be related to their availability also. Agave plants are common in Rancho el Plomito and reach densities of 683 agaves/ha (Tarango 2000). The elephant tree is an important food source for bighorn sheep during hot and dry seasons. This plant is present year round and was the only green forage available to bighorns during the hottest and driest seasons. Other plants that did not occur in the diet analysis, but were observed being eaten by sheep were limber bush (Jatropha cuneata Wiggins \& Rollins) a plant preferred by lambs, coursetia and salvia by males and females.

Forbs were more important during wet conditions (winter and summer) and less during dry conditions (spring and autumn) (Fig. 2). Content of globemallow in the diet ranged from 5.5 to $38.0 \%$ and averaged $19.5 \%$. This forb has also been reported to be an important component of diets of bighorns in other areas (Sanchez 1976, Krausman et al. 1989, Bleich et al. 1992), and in mule deer (Anderson et al. 1965, Leopold and Krausman 1987). In the Santa Catalina Mountains, Arizona, forbs were always higher in protein than browse and grasses throughout the year (Mazaika et al. 1992). Furthermore, Morgart et al. (1986) report that forbs in the spring contained more phosphorus and protein than browse and grasses eaten by bighorns. In addition, in winter, annuals enhanced the physical condition of females during late pregnancy and early lactation (Smith and Krausman 1987).

Forage categories used by bighorn sheep in Rancho el Plomito, Sonora, Mexico were similar to desert bighorn sheep diets in Arizona (Etchberger 1993). Grasses constituted a small portion of diets of bighorn sheep in Rancho el Plomito. Browning and Monson (1980) state that wild sheep of the world are grazers. The preference for browse over grass species is due to their availability rather than preferences (Seegmiller and Ohmart 1982).

Desert bighorn sheep in Sonora exhibited temporal segregation, however, spatial separation by sexes was not clearly defined and consequently differences in composition of diets of males and females during segregation (autumn, winter, spring) were not noticeable. We encountered groups of males and females using the same foraging areas at different times. Furthermore we found no difference of diet diversity for any of the seasons within years and during the nonbreeding period. Males and females in our study area shared most of the plants species throughout the study and used them in similar proportions.

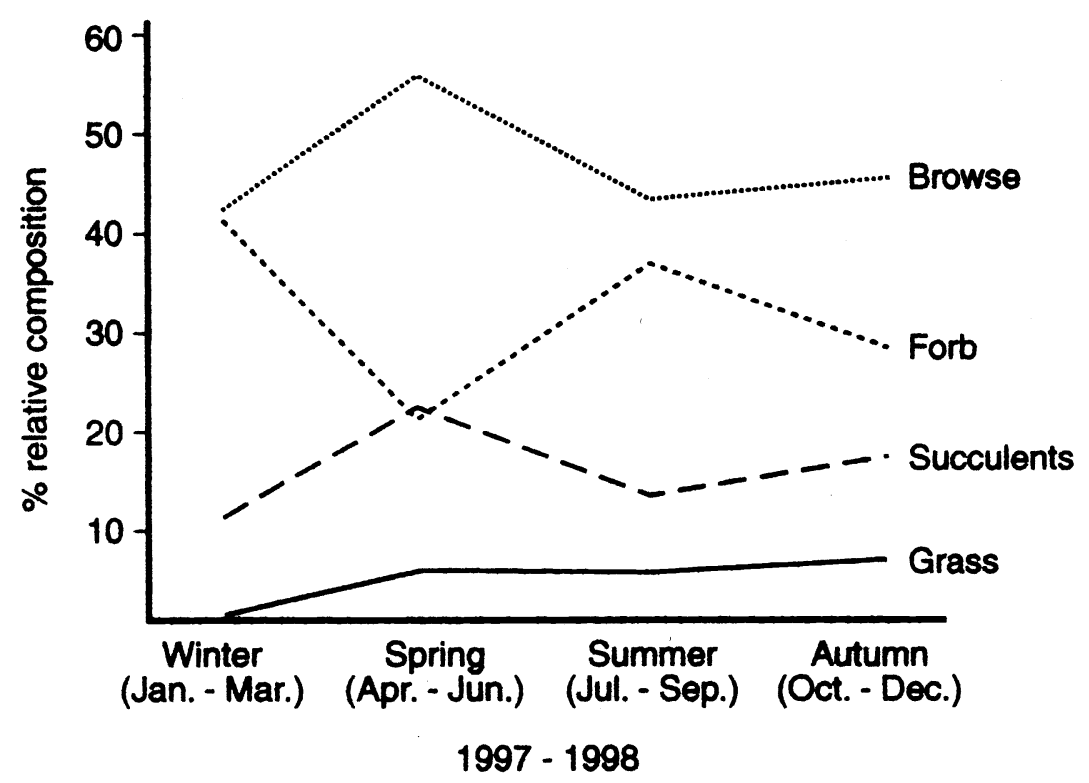

Fig. 2. Consumption of browse, forbs, succulents, and grass by desert bighorn sheep, Rancho el Plomito, Sierra el Viejo, northwestern Sonora, Mexico, 1997-1998. 


\section{Management Implications}

The diet of males and females was not significantly different and bighorn sheep consumed 41 plant species from April 1997 to December 1998 in Rancho el Plomito, Sonora. These data are important for the successful translocations of bighorn sheep in Mexico. Attempts to repopulate landscapes where bighorn sheep have been extripated, in Sonora and Baja California Sur, are being conducted by private organizations and the Mexican government (Jimenez et al. 1996, 1997). In the process of identifying potential release sites, studies of diet composition will provide managers with information essential for successful translocations. We suggest that studies of translocation sites, including the vegetation resource base, be conducted prior to translocations or habitat alteration.

\section{Literature Cited}

Alcoze, T.M. and E.G. Zimmerman. 1973. Food habits and dietary overlap of two heteromyid rodents from the mesquite plains of Texas. J. Mamm. 54:900-908.

Alderman, JA., PR. Krausman, andB.D. Leopold. 1989. Diet activity of female desert bighorn sheep in western Arizona. J. Wildl. Manage. 1:264-271.

Anderson, A.E., W. A. Snyder, and G.W. Brown. 1965. Stomach content analyses related to condition in mule deer, Guadalupe Mountains, New Mexico. J. Wildl. Manage. 29:352-366.

Bleich, V.C., R.T. Bowyer, DJ. Clark, and T.O. Clark. 1992. Analyses of forage eaten by mountain sheep in the Mojave Desert, California. Desert Bighorn Counc.Trans. 36:41-47.

Brown, R.T. 1994. Biotic communities: Southwestern United States and Mexico. Univ. Utah Press, Salt Lake City, Utah.

Browning, B.M. and G. Monson. 1980. Food, p. 80-99. In: G. Monson and L. Sumner, (eds), The desert bighorn. The Univ. Ariz. Press, Tucson, Ariz.

Elenowitz, A.S. 1983. Habitat use and population dynamics of transplanted desert bighorn sheep in the Peloncillo Mountain. M.S. Thesis, New Mexico State Univ., Las Cruces, N.M.

Etchberger, R.C. 1993. Mountain sheep microsite habitat characteristics in western Arizona. Ph.D. Thesis, Univ. Arizona, Tucson, Ariz.

Fracker, S.B. and H. A. Brischle. 1944. Measuring the local distribution of ribes. Ecol. 25:283-303.

Geist, V. 1968. On the interrelation of external appearance, social behavior and social structure of mountain sheep. Z. Tierpsychol. 25:199-215
Gill, R.B., L.H. Carpenter, R.M. Bartman, D.L. Baker, and G.G. Schoonveld. 1983. Fecal analysis to estimate mule deer diets. J. Wildl. Manage. 47:902-915.

Hernandez, C.M.C. 1998. Caracterización de la vegetación del predio "El Plomito", municipio de Pitiquito, Sonora, México. Tesis Profesional, Universidad Autónoma de Nuevo León. 85pp.

Holechek, J.L. and M. Vavra. 1981. The effect of slide and frequency observation numbers on the precision of micro histological analysis. J. Range Manage. 34:337-338.

Holechek, J.L., M. Vavra, and R.D. Pieper. 1982. Botanical composition determination of range hervibore diets a review. J. Range Manage. 35:309-315.

Horn, H.S. 1966. Measurement of "overlap" in comparative ecological studies. Amer. Nat. 100:419-424.

Jimenez, S., C. Hernandez, J.R. DeForge, and R. Valdez. 1996. Desert bighorn sheep (Ovis canadensis weemsi) recovery project in Baja California Sur, Mexico. Desert Bighorn Counc. Trans. 40:8-12.

Jimenez, S., C. Hernandez, J.R. DeForge, and R. Valdez. 1997. Update of the conservation plan for Weems desert bighorn on Carmen Island, Baja California Sur, Mexico. Desert Bighorn Counc. Trans. 41:44-50.

Krausman, P.R., B.D. Leopold, R.F. Seegmiller, and S.C. Torres. 1989. Relationships between desert bighorn sheep and habitats in western Arizona. Wildl. Monogr. 102.

Lee, R. and E. Lopez-Saavedra. 1994. A second helicopter survey of desert bighorn sheep in Sonora, Mexico. Desert Bighorn Counc. Trans. 38:12-13.

Lehr, J.H. 1978. A catalogue of the flora of Arizona. Desert Botanical Garden, Phoenix, Arizona. Northland Press, Flagstaff, Ariz.

Leopold, B.D., and P.R. Krausman. 1987. Diets of two desert mule deer herds in Big Bend National Park, Texas. Southwest. Nat. 323:449-455.

Mazaika, R., P.R. Krausman, and R.C. Etchberger. 1992. Nutritional carrying capacity of desert bighorn sheep habitat in the Pusch Ridge Wilderness, Arizona. Southwest. Nat. 37:372-378.

Morgart, J.R., P.R. Krausman, W.H. Brown, and F.M. Whiting. 1986. Chemical analysis of mountain sheep forage in the Virgin Mountains, Arizona. Univ. Arizona, Coll. Agr. Tech. Bull. 257. Tucson, Ariz.

Morisita, M. 1959. Measuring of interspecific association and similarity between communities. Mem. Fac. Sci. Kyushu Univ., Ser. E. Biol. 3:65-80.

Sadlier, R.M.F.S. 1969. The ecology of reproduction in wild and domestic mammals. Methuen Publ., London, U.K.

Sanchez, D.R. 1976. Analysis of stomach contents of bighorn sheep in Baja California. 1976. Desert Bighorn Counc. Trans. 20:21-22.

Seegmiller, R.F. and R.D. Ohmart. 1982. Desert bighorn lamb and adult-yearling diets from western Arizona. Desert Bighorn Counc. Trans. 26:34-38.
Smith, D.R. and P.R. Krausman. 1987. Diets of desert bighorns in the Virgin Mountains, Arizona. Desert Bighorn Counc. Trans. $31: 11-14$.

Sparks, D.R. and J.C. Malecheck. 1968. Estimating percentage dry weight in diets using a microscopic technique. J. Range Manage. 21:264-265

Tarango, L.A. 2000. Desert Bighorn sheep in Mexico. Ph.D. Diss., Univ. Arizona, Tucson, Ariz.

Warrick, G.D., and P.R. Krausman. 1989. Barrel cacti consumption by desert bighorn sheep. Southwest. Nat. 34:483-486.

Zar, J.H. 1996. Biostatistical Analysis. Third ed. Prentice Hall, Upper Saddle River, N.J. 